\title{
Laitostuotetetuissa komposteissa on taudinestokykyä
}

\author{
Mauritz Vestberg ${ }^{1}$, Sanna Kukkonen ${ }^{1}$, Päivi Parikka ${ }^{2}$, Dan $\mathrm{Yu}^{3}$, Jukka Kurola ${ }^{3}$, Martin Romantschuk ${ }^{3}$ \\ ja Heikki Setälä ${ }^{3}$ \\ ${ }^{1}$ MTT/ Kasvintuotannon tutkimus, Taimistoryhmä, Antinniementie 1, 41330 Vihtavuori \\ ${ }^{2}$ MTT/ Kasvintuotannon tutkimus, kasvinsuojelu, 31600 Jokioinen \\ ${ }^{3}$ Helsingin Yliopisto, Ympäristöekologian laitos, Niemenkatu 73, 15140 LAHTI
}

Kompostien kykyä ehkäistä maalevintäisiä kasvitauteja on Suomessa tutkittu vain vähän. Vuonna 2008 käynnistyi Suomi - Intia projekti, jossa selvitetään mm. 1) esiintyykö suomalaisissa laitoskomposteissa estokykyä maalevintäisiä kasvitauteja vastaan, 2) löytyykö taudinestokykyä useampaa kasvitautia vastaan, 3) toistuuko taudinestokyky samoista raaka-aineista tehdyissä eri kompostierissä ja 4) liittyykö kompostien taudinestokyky kompostien mikrobikoostumukseen.

Kokeissa oli mukana 21 kompostierää, jotka olivat peräisin kompostointilaitoksilta ympäri Suomea. Kompostien raaka-aineina olivat biojäte, puutarhajäte, metsäteollisuuden ja jätevesipuhdistamon liete sekä karjan-, hevosen- ja siipikarjan lanta. Komposteista 8 oli tuotettu aumoissa, 8 tunneleissa, 3 rummuissa ja 2 muulla tavoin. Tehtiin kolme taudinestokoetta, joista kahdessa ensimmäisessä oli mukana kaikki 21 kompostia. Ensimmäisessä kokeessa tutkittiin kompostien kykyä ehkäistä mansikan (lajike 'Jonsok') tyvimätää (aiheuttajana Phytopthora cactorum) ja toisessa avomaakurkun ('Parmel') lakastumistautia (Pythium spp.). Kolmanteen kokeeseen valittiin lupaavimmilta näyttäneet 7 kompostia, yksi neutraali komposti ja yksi tautia lisäävä komposti. Näistä komposteista vertailtiin vuonna 2008 ja 2009 valmistuneita eriä. Taudinkestokokeista valittiin 12 kompostia mikrobikoostumuksen selvittämiseen molekyylibiologisin menetelmin HY:ssa. Kompostin bakteerien 16S ribosomaalisen RNA-geenin osa sekä sienten ribosomaalisen RNA:n transkriptoitu geenienvälinen alue, ns. ITS alue, monistettiin PCR reaktion avulla käyttäen alukkeita, joihin oli lisätty ns. GC-uloke denaturoivaa gradienttigeelielektroforeesia (DGGE) varten. Yleisimmät bakteerit ja sienet eroteltiin toisistaan DGGE geelissä ja tunnistettiin edelleen sekvensoimalla.

Useiden kompostien osoitettiin ehkäisevän tyvimätää mansikalla, lakastumistautia kurkulla tai molempia. Kolme komposteista ehkäisi selvästi molempia kasvitauteja. Tämän lisäksi mansikan tyvimätää ehkäisi enemmän tai vähemmän 6 ja kurkun lakastumistautia 11 kompostia. Suljetuissa kompostointireaktoreista tuotetuista komposteista oli suurempi osuus kasvitauteja ehkäiseviä kuin aumoissa tuotetuista. Kompostierien vertailukoe osoitti, että taudinehkäisykyky näyttäisi pääsääntöisesti toistuvan. Jotta kompostin taudinestokykyä voitaisiin hyödyntää kasvihuoneviljelyssä, tulisi pystyä tuottamaan sekä kemialliselta että biologiselta laadultaan riittävän tasalaatuista kompostia.

DGGE tekniikalla eroteltiin 279 bakteeri- ja 166 sienispesifistä juovaa, jotka tunnistettiin sekvensoimalla. Kypsille komposteille tyypilliset Proteobakteerit (87 \%), erityisesti Gammaproteobakteerit (85 \% Proteobakteereista), muodostivat bakteerien valtaryhmän mansikkakokeen kasvualustassa, kun taas yleisin sieniryhmä oli Ascomycota (65 \%). Kurkkukokeessa Proteobakteereja edusti 70 \% kaikista sekvensseistä kokeen alussa, mutta kokeen lopussa niiden osuus putosi 38 \%:iin. Samalla Bacteroidetes nousi suurimmaksi bakteeri ryhmäksi edustaen $54 \%$ kaikista sekvensseistä. Sienipopulaatiossa Ascomycota oli yleisin sekä kokeen alussa (67 \%) että lopussa (58 \%). Mikrobipopulaatioiden tarkempi analyysi ja kompostien vertailu ovat edelleen käynnissä, joten tautia ehkäisevien ja ei-ehkäisevien kompostien mikrobistojen mahdollisesta erilaisuudesta ei ole vielä lopullisia tuloksia.

Asiasanat: komposti taudinestokyky, Phytophthora, Pythium, DGGE, mikrobipopulaatio 


\section{Johdanto}

Kompostiksi voidaan lukea mikä tahansa orgaaninen aines, joka on läpikäynyt termofiilisen, pitkän ja aerobisen hajoamisprosessin. Komposti on maanparannusaine, jonka vaikutukset kuitenkin ovat moninaisia. Se vaikuttaa maaperän ja kasvualustan ravinnepitoisuuteen, rakenteeseen, huokoisuuteen, orgaaniseen ainekseen, vedenpidätyskykyyn ja maalevintäisten kasvitautien estokykyyn (Itävaara ym. 1997).

Kompostien taudinestokyky mainittiin ensimmäistä kertaa yli kolme vuosikymmentä sitten kun Amerikassa oli havaittu, että havupuun kuoresta tehty komposti esti Fusarium oxysporum f.sp. chrysantemi -sienen aiheuttamaa krysanteemin juurilahoa (Hoitink \& Poole 1976). Sen jälkeen taudinestokykyä on todettu hyvin monenlaisia kasvitauteja vastaan, esim. Pythium (McKellar \& Nelson 2003), Phytophthora (Hoitink \& Boehm, 1999), Rhizoctonia (Nakasaki ym.1998), Fusarium (Suárez-Estrella ym. 2007), Sclerotinia (Boulter ym. 2002), Sclerotium (Gorodecki \& Hadar 1990) ja Verticillium (Termorshuizen ym. 2006) sienten aiheuttamiin maalevintäisiin kasvitauteihin. Myös patogeenisia bakteereita (Schönfeld ym. 2003) ja kasveja vioittavia ankeroisia (Oka \& Yermiyahu 2004) on pystytty torjumaan kompostia käyttämällä.

Taudinestokykyä löytyy lähinnä vain kypsistä komposteista (Kuter ym. 1988; Hadar and Gorecki 1991). Poikkeuksena tähän yleissääntöön on kuitenkin esim. Danon ym. (2007) tutkimus, missä Sclerotium rolfsii -patogeenin pahkoja tuhoavat mykoparasiittiset sienet vähenivät kompostin kypsyessä. Raviv (2008) toisaalta totesi, että Fusarium oxysporum f.sp. melonis patogeenia torjuva komposti alkoi menettää taudinestokykyään vuosi kompostin tuottamisen jälkeen. Kahden vuoden päästä taudinestokyky oli enää 50\% alkuperäisestä.

Taudinestomekanismien ymmärtäminen on tärkeää, jotta taudinestoilmiötä voitaisiin hyödyntää. Ilmiön selittäjiksi on ehdotettu kompostien biologisia, kemiallisia ja fysikaalisia ominaisuuksia (Hoitink \& Boehm 1999; Raviv 2009). Mekanismeista mainittakoon (1) kompostimikrobien ja patogeenien kilpailu ravinteista (Chen ym. 1988), tilasta (Serra-Wittling ym. 1996) tai infektoitumiskohdista (Benhamou \& Garand 2001), 2) hyperparasitismi (Gorodecki \& Hadar 1990), 3) antibioosi (Raviv 2009), 4) kompostin aiheuttama patogeeni-itiöiden ennenaikainen itäminen (Yogev ym. 2006) ja 5) kasvin systeemisesti virittynyt kestävyys taudinaiheuttajia vastaan (Zhang ym. 1998).

Kompostien käyttöä maalevintäisten kasvitautien torjunnassa on Suomessa tutkittu vain vähän. Tällä hetkellä emme tiedä tarkkaan onko suomalaisissakin komposteissa olemassa taudinestoominaisuuksia. Vuonna 2008 käynnistyi kansainvälinen Suomi - Intia projekti, jonka tavoitteena on tutkia ja hyödyntää kompostien taudinestokykyä. Suomessa hankkeeseen osallistuvat MTT, HY ja Eviran hyväksymiä laitoskompostoijia. Tutkimuksessa selvitetään mm:

1. Esiintyykö Eviran hyväksymissä suomalaisissa laitoskomposteissa estokykyä maalevintäisiä kasvitauteja vastaan?

2. Löytyykö taudinestokykyä useampaa kasvitautia vastaan?

3. Toistuuko taudinestokyky samoista raaka-aineista tehdyissä eri kompostierissä?

4. Liittyykö kompostien taudinestokyky kompostien mikrobikoostumukseen?

\section{Aineisto ja menetelmät}

\section{Kompostit}

Kokeissa oli mukana 21 kompostierää, jotka olivat peräisin kompostointilaitoksilta ympäri Suomea (Kuva 1). Kompostinäytteet kerättiin keväällä 2008 ja 2009. Kompostien raaka-aineet, sidosaineet ja kemialliset ominaisuudet vaihtelivat suuresti (Taulukko 1). Kompostien raaka-aineina olivat biojäte, puutarhajäte, metsäteollisuuden ja yhdyskuntien jätevesiliete sekä karjan-, hevosen-, ja siipikarjan lanta. Kompostien sidos- tai tukiaineena oli käytetty turvetta, puupaloja, kuorta, olkea tai puun oksia. 
Myös kompostointitapa vaihteli. Aluksi mukana oli 8 aumakompostia, 8 tunnelikompostia, 3 rumpukompostia ja 2 kompostia, jotka oli tuotettu suljettujen reaktoreiden yhdistelmänä. Kompostierien vertailukokeeseen valittiin 9 kompostia, joista vertailtiin keväällä 2008 ja 2009 valmistuneita eriä.

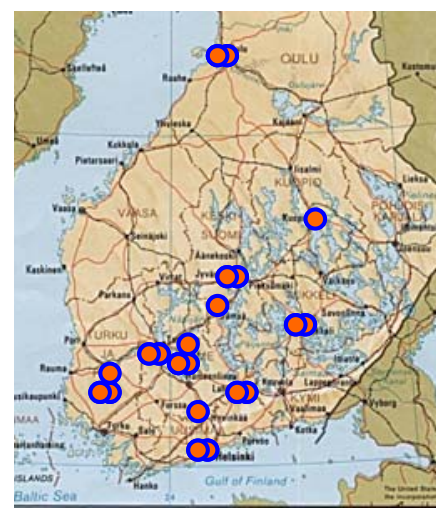

Kuva 1. Kompostitutkimuksessa mukana olevat kompostilaitokset

Taulukko 1. Kompostointiprosessi, raaka-aineet sekä joitakin kompostien kemiallisia ominaisuuksia. Kullekin kompostille on annettu juokseva numero (1-21). Ryhmittely on tehty kompostointiprosessin mukaan.

\begin{tabular}{|c|c|c|c|c|c|c|c|c|}
\hline \multirow[b]{2}{*}{ Nro } & \multirow[b]{2}{*}{$\begin{array}{l}\text { Kompostointi- } \\
\text { prosessi }\end{array}$} & \multirow[b]{2}{*}{$\begin{array}{l}\text { Kompostin raaka- } \\
\text { aineet }\end{array}$} & \multicolumn{6}{|c|}{ Kemialliset ominaisuudet } \\
\hline & & & $\mathrm{pH}$ & $\begin{array}{c}\mathrm{EC} \\
(1+5) \\
\mathrm{mS} \mathrm{cm}^{-1}\end{array}$ & $\begin{array}{c}\mathrm{P}_{\mathrm{kok}} \\
\mathrm{g} \mathrm{kg}^{-1}\end{array}$ & $\begin{array}{l}\mathrm{N} \\
\%\end{array}$ & $\begin{array}{l}\mathrm{C} \\
\%\end{array}$ & $\begin{array}{l}\mathrm{C} / \mathrm{N} \\
\text { suhde }\end{array}$ \\
\hline 6 & auma & K.lanta + P.jäte & 7.0 & 0.8 & 2.7 & 1.4 & 24 & 17.5 \\
\hline 10 & auma & H. + K.lanta & 8.1 & 2.2 & 4.3 & 1.7 & 39.7 & 23.9 \\
\hline 5 & auma & H.lanta + M.liete & 5.3 & 0.5 & 3.2 & 1.7 & 47.6 & 27.9 \\
\hline 4 & auma & M.liete & 7.6 & 1.0 & 1.7 & 1.2 & 36.1 & 30.8 \\
\hline 11 & auma & J.liete & 6.4 & 0.4 & 14.7 & 1.2 & 34.7 & 29.0 \\
\hline 19 & auma & J.liete + K.lanta & 6.8 & 3.5 & 14.6 & 3.0 & 36.3 & 12.1 \\
\hline 12 & auma & Kasvinjäte & 7.5 & 0.4 & 1.8 & 0.8 & 23.4 & 27.6 \\
\hline 1 & auma & SK.lanta & 7.8 & 3.7 & 17.9 & 3.2 & 41.1 & 13.0 \\
\hline 2 & suljettu reaktori & M.jäte + SK.lanta & 7.7 & 0.3 & 3.2 & 1.3 & 40.8 & 31.6 \\
\hline 15 & rumpu & B.jäte & 7.3 & 1.5 & 3.8 & 1.6 & 25.3 & 15.3 \\
\hline 16 & rumpu & B.jäte & 6.9 & 2.0 & 3.1 & 2.3 & 33.9 & 14.6 \\
\hline 3 & rumpu & B.jäte & 6.0 & 0.2 & 3.0 & 3.7 & 44.8 & 11.9 \\
\hline 7 & rumpu + tunneli & B.jäte & 8.2 & 1.4 & 3.2 & 1.8 & 32.8 & 18.0 \\
\hline 13 & tunneli & B.jäte & 7.5 & 0.5 & 7.1 & 2.8 & 33.7 & 12.0 \\
\hline 20 & tunneli & B.jäte & 7.8 & 4.0 & 4.7 & 2.1 & 23.5 & 11.1 \\
\hline 8 & tunneli & B.jäte + P.jäte & 7.1 & 1.1 & 7.0 & 3.4 & 33.0 & 9.8 \\
\hline 21 & tunneli & P.jäte & 8.0 & 0.6 & 1.1 & 0.8 & 14.6 & 18.4 \\
\hline 14 & tunneli & J.liete & 5.1 & 1.3 & 21.6 & 1.9 & 28.1 & 15.0 \\
\hline 17 & tunneli & J.liete + B.jäte & 5.4 & 1.2 & 29.2 & 2.7 & 29.3 & 10.9 \\
\hline 18 & tunneli & J.liete + B.jäte & 5.4 & 0.8 & 31.5 & 2.6 & 26.5 & 10.1 \\
\hline 9 & tunneli & J.liete + P.jäte & 6.2 & 1.7 & 20.7 & 2.2 & 28.0 & 12.9 \\
\hline
\end{tabular}

$\mathrm{K}=$ karja, $\mathrm{H}$ = hevonen, $\mathrm{SK}=$ siipikarja, $\mathrm{P}=$ puutarha, $\mathrm{M}$ = metsäteollisuuden, $\mathrm{J}$ = jäte, $\mathrm{B}=$ bio 


\section{Taudinestokokeet}

Kolme taudinestokoetta tehtiin MTT:n kasvihuoneessa Jokioisilla. Kahdessa ensimmäisessä oli mukana kaikki 21 kompostia. Ensimmäisessä kokeessa tutkittiin kompostien ehkäisyvaikutusta 'Jonsok' mansikan tyvimätään (aiheuttaja Phytopthora cactorum) ja toisessa 'Parmel' avomaankurkun lakastumistautiin (Pythium spp.). Kolmanteen kokeeseen valittiin lupaavimmilta näyttäneet 7 kompostia, yksi neutraali komposti ja yksi tautia lisäävä komposti. Näistä komposteista vertailtiin vuonna 2008 ja 2009 valmistuneita eriä.

Kaikissa kokeissa kompostia käytettiin 20\% höyrytettyyn turvepitoiseen kasvualustaan sekoitettuna. Turve-komposti -seoksia kalkittiin ja lannoitettiin eri tavalla riippuen kompostien ravinnepitoisuusta ja pH:sta. Valmiin kasvualustan tavoitearvot olivat pH 6-6.5, johtoluku 4-8, N 250 mg, P 100 mg ja K 350 mg/l alustaa. Mansikkakoetta ei lannoitettu kokeen aikana, mutta kurkuille annettiin Puutarhan Täyslannosta kerran viikossa kastelun yhteydessä.

Mansikkakoe kesti 6 viikkoa ja siinä käytettiin turpeella kasvaneita, 6 viikkoa vanhoja 'Jonsok' mikrotaimia. Phytophthora-saastutus tehtiin vuorokausi taimien istuttamisen jälkeen, jolloin saastutettaville taimille annosteltiin 100 ml vettä, joka sisälsi keskimäärin 3200 sienen munapesäkkettä. Kontrollitaimille annettiin saman verran vettä. Taimien lehvästön kunto havainnoitiin kerran viikossa. Kokeen lopussa havainnoitiin myös juurakon ruskettuneisuus sekä määritettiin versojen tuore- ja kuivapaino.

Ensimmäinen kurkkukoe kesti myös kuusi viikkoa ja siinä käytettiin 10 päivää vanhoja, siemenistä kasvatettuja "Parmel” taimia. Istuttamisen yhteydessä saastutettaville taimille annosteltiin 10 g agaralustaa, missä oli Pythium-sienirihmoja. Kontrollitaimille annettiin 10 g agaria ilman taudinaiheuttajasientä. Kokeen aikana mitattiin taimien pituus, laskettiin lehtien lukumäärä sekä arvioitiin taimien kunto. Loppuvaiheessa arvioitiin juuriston määrä ja kunto sekä punnittiin lehvästön tuore- ja kuivapaino. Toinen kurkkukoe toteutettiin muuten samalla tavalla kuin ensimmäinen, mutta kesto oli vain 5 viikkoa.

\section{Kompostien mikrobit}

Mikrobiologisia analyysejä varten valittiin mansikan ja kurkun taudinkestokokeista 12 kompostia kummastakin. Kompostista eristettiin kokonais-DNA käyttäen kaupallista Fast DNA® SPIN for soil kit (MP Biomedicals) menetelmää valmistajan ohjeiden mukaisesti. Kompostin bakteerien 16S ribosomaalisen RNA-geenin osa, sekä sienten ribosomaalisen RNA:n transkriptoitu geenienvälinen alue, ns. ITS alue, monistettiin PCR reaktion avulla käyttäen alukkeita, joihin oli lisätty ns. GC-uloke denaturoivaa gradienttigeelielektroforeesia (DGGE) varten. Kompostinäytteiden yleisimmät bakteerit ja sienet eroteltiin toisistaan DGGE geelissä ja tunnistettiin edelleen sekvensoimalla, kuten selostettu aikaisemmin (Hultman ym. 2009). Tiettyyn bakteerilajiin kuuluviksi tunnistettiin ne geenisekvenssit, joiden samankaltaisuus oli > $97 \%$ kuin geenikirjastosta löydetyn bakteerilajin sekvenssin.

\section{Tulokset ja tulosten tarkastelu}

\section{Taudinesto}

Useiden kompostien osoitettiin ehkäisevän tyvimätää mansikalla, lakastumistautia kurkulla tai molempia. Kolme 21 tutkitusta kompostista ehkäisi selvästi molempia kasvitauteja (kompostit 5, 14 ja 17). Tämän lisäksi tyvimätää (taudinaiheuttaja Pythium ultimum) ehkäisi enemmän tai vähemmän 6 ja lakastumistautia (Phytophthora cactorum) 11 kompostia (Kuva 2). Kompostien väliset erot oli helpompi havaita Pythium -taudin kuin Phytophthora -taudin perusteella, sillä kasvun hidastuminen oli selvempää kurkulla kuin mansikalla. Molemmissa tapauksissa taudin esiintyminen oli jonkin verran epätasaista, mikä vaikeutti erojen havaitsemista.

Taudinehkäisykyvyn vaihtelua kompostierissä selvittävään kokeeseen oli valittu mukaan edellisten kokeiden perusteella 8 tautia ehkäisevää kompostia, yksi tautia lisäävä (komposti 1) sekä yksi tau- 
din ilmenemiseen vaikuttamaton komposti (6). Kokeessa verrattiin samalta laitokselta eri vuosina, mutta samaan vuodenaikaan otettuja kompostieriä. Taudinehkäisykyky näyttäisi pääsääntöisesti toistuvan (Kuva 3). Pariin kompostiin liittyy kuitenkin epävarmuutta suuren hajonnan vuoksi.

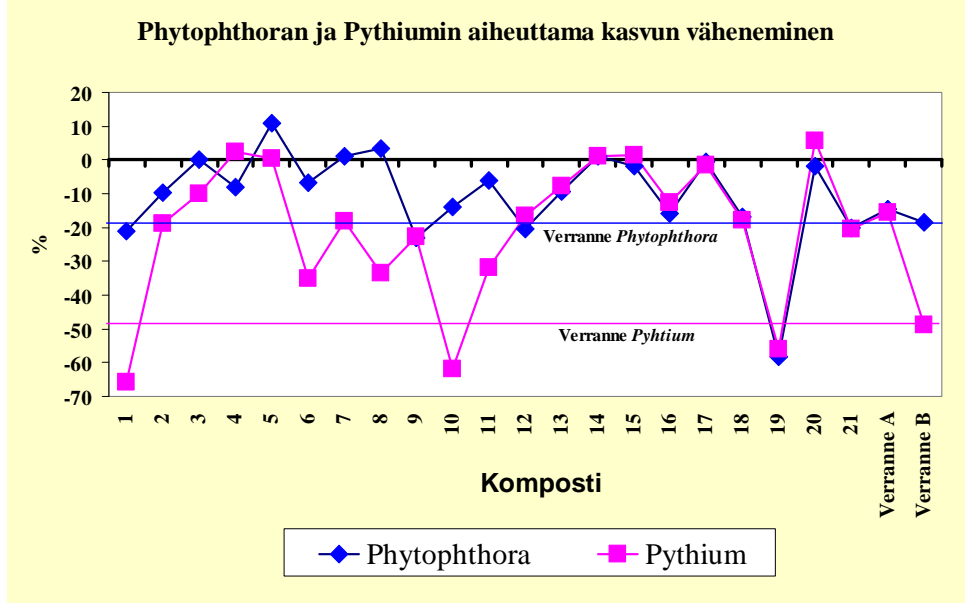

Kuva 2. Laitostuotettujen 21 kompostin suhteelliset vaikutukset kahteen erilaiseen kasvitautiin. Vaikutukset mansikan tyvimätään (Phytophthora cactorum) ja kurkun lakastumistautiin (Pythium spp.) ilmaistuna tautisaastutettujen ja saastuttamattomien taimien kuivapainoerona kokeiden lopussa.

Kuten tässä tutkimuksessa, myös ulkomaisissa tutkimuksissa on osoitettu, että yhtä kasvitautia ehkäisevä komposti ei välttämättä torju toista (Termorshuizen 2006). Tämä vaikeuttaa kompostien hyödyntämistä kasvitautien ehkäisyssä. Taudinehkäisykyvyn vaihtelu kompostierästä toiseen ei kuitenkaan näyttäisi olevan ongelmana suomalaisissa komposteissa. Samalta laitokselta tulevissa kompostierissä saattaa olla suuria vaihteluja ravinnepitoisuuksien ja $\mathrm{pH}: n$ suhteen. Tämä ei välttämättä aiheuta muutoksia kasvitautien estossa, kun vaihtelu huomioidaan kalkituksen ja lannoituksen mitoituksessa.

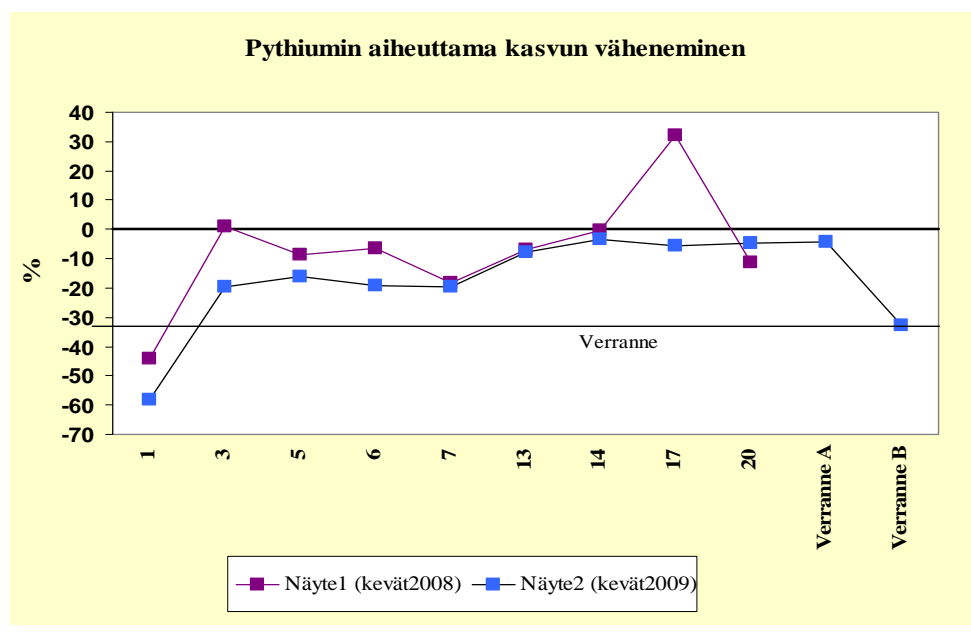

Kuva 3. Samoista raaka-aineista tehtyjen eri erien vaikutus kurkun lakastumistautiin (Pyhtium spp. ilmaistuna tautisaastutettujen ja saastuttamattomien taimien kuivapainoerona kokeen lopussa.

Tulosten perusteella voi myös alustavasti tarkastella kompostointimenetelmän ja raaka-aineen vaikutusta taudinehkäisykykyyn. Suljetuissa kompostointireaktoreista tuotetuista komposteista oli suurempi osuus kasvitauteja ehkäiseviä kuin aumoissa tuotetuista. Reaktoreista yleisimpiä ovat tunnelit ja rummut, joissa komposti käy läpi lämpövaiheen. Tämän jälkeen kompostit yleensä siirretään ulos aumoihin jälkikypsymään. Reaktoreissa tuotetut kompostit saattavat sisältää vähemmän erilaisia pien- 
eliöitä kuin kokonaan aumoissa tuotetut (Kuter ym. 1993). Tunnetun kompostitutkijan Hoitinkin mukaan reaktoreissa valmistetut kompostit vaativatkin pidemmän jälkikypsytysajan, jotta niistä tulee kasvitauteja ehkäiseviä (Hoitink ym. 1997).

Myös kompostin raaka-aineilla voi olla vaikutusta taudinehkäisykyvyn syntyyn. Reaktoreissa tuotetuista komposteista parhaiten tyvimätää tai lakastumistautia torjuvat oli valmistettu pääasiassa biojätteestä ja puhdistamolietteistä. Ulkomaisissa tutkimuksissa on osoitettu, että myös kompostoitu puunkuori torjuu hyvin Phytophthora ja Pythium -sienten aiheuttamia kasvitauteja (Hoitink ym. 1997).

\section{Taudinestokompostien mikrobit}

DGGE tekniikalla eroteltiin 279 bakteeri- ja 166 sienispesifistä juovaa, jotka tunnistettiin sekvensoimalla. Kypsille komposteille tyypilliset Proteobakteerit (87 \%), erityisesti Gamma-proteobakteerit (85 $\%$ kaikista proteobakteereista), muodostivat bakteerien valtaryhmän mansikkakokeen komposteissa, kun taas Ascomycotaa edustivat $65 \%$ kompostin kaikista sienistä (Kuva 4a).

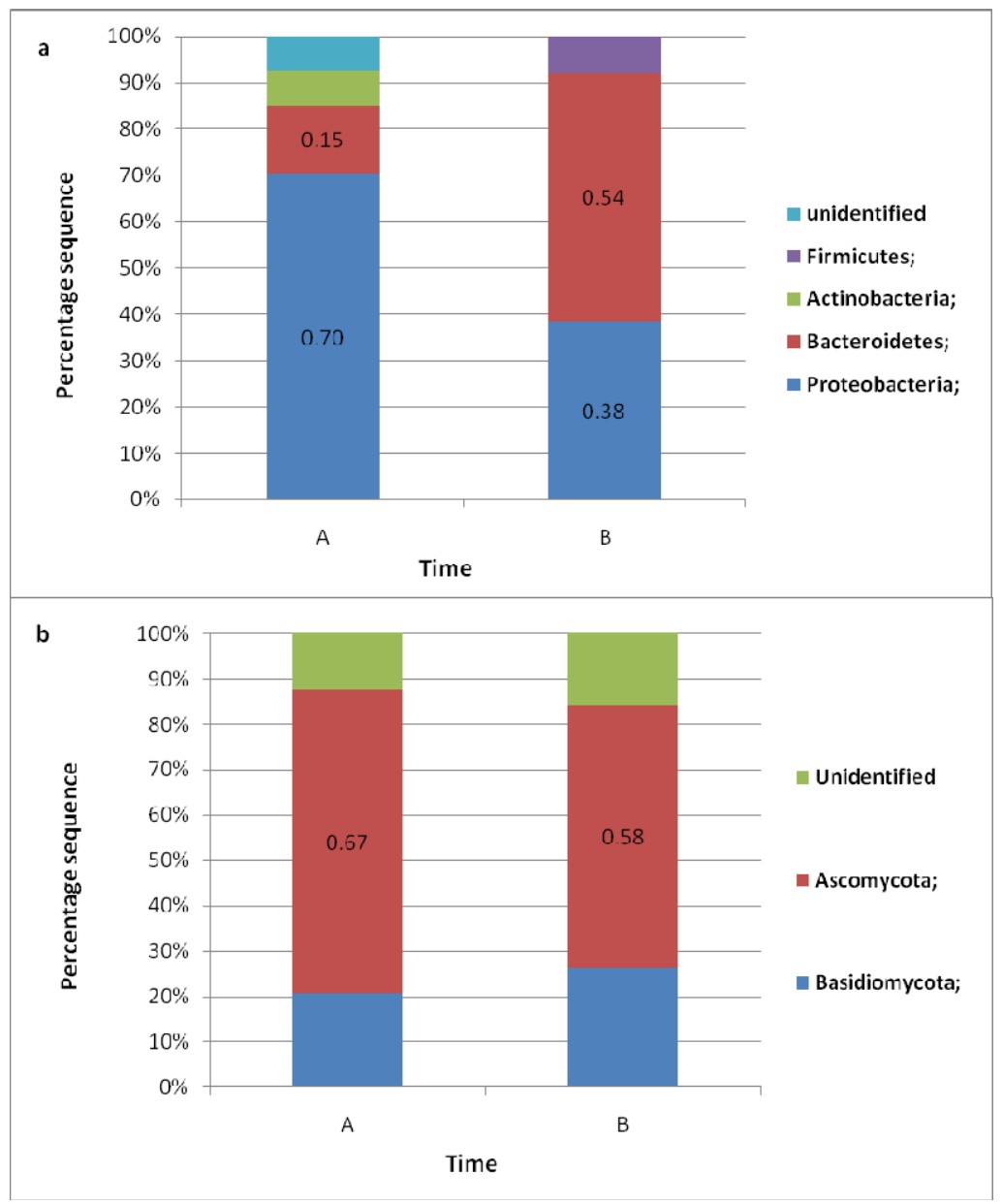

Kuva 4. Kompostin mikrobiyhteisöt esitettynä pääluokkatasolla kurkkukokeessa. a, bakteeriyhteisöt; b, sieniyhteisöt. Tuloksiin on yhdistetty 12 kompostiseoksen tulokset. A, kokeen alussa otetut näytteet; B, kokeen lopussa otetut näytteet.

Kurkkukokeissa Proteobakteereja edusti 70 \%:a kaikista sekvensseistä kokeen alussa, mutta kokeen lopussa niiden osuus putosi 38 \%:iin. Samalla Bacteroidetes nousi suurimmaksi bakteeri ryhmäksi edustaen 54 \% kaikista sekvensseistä, mikä kuvastaa kokeen aikana tapahtunutta kompostin eri bak- 
teeripopulaatioiden välistä sukkessiota (Kuva 4a). Sienipopulaatiossa Ascomycota oli yleisin sekä kokeen alussa (67 \%) että lopussa (58 \%; Kuva 4b). Mikrobipopulaatioiden tarkempi analyysi ja kompostien vertailu ovat edelleen käynnissä, joten tautia ehkäisevien ja ei-ehkäisevien kompostien mikrobistojen mahdollisesta erilaisuudesta ei ole vielä lopullisia tuloksia.

\section{Johtopäätökset}

Suomalaisissa kompostointilaitoksissa tuotetuilla komposteilla voidaan ehkäistä joitakin kasvitauteja kasvihuoneviljelyssä. Kompostien välillä on kuitenkin eroja tässä suhteessa. Jotta tätä ominaisuutta voitaisiin hyödyntää kasvihuoneviljelyssä, tulisi pystyä tuottamaan sekä kemialliselta että biologiselta laadultaan riittävän tasalaatuista kompostia. Tähän liittyen tulisi selvittää tarkemmin raaka-aineiden ja tuotantoprosessin vaikutusta kompostin laatuun. Ravinnepitoisuuksien ja $\mathrm{pH}: n$ vaihtelut samalta laitokselta tulevissakin kompostierissä saattaa olla huomattavat. Tämän vuoksi kompostit soveltuvatkin paremmin maanparannusaineiksi. Taudinehkäisykyvyn toimivuutta avomaaolosuhteissa ei kuitenkaan vielä tiedetä, ja tämä seikka vaatisi lisää tutkimusta.

Vertailtaessa eri tavalla käyttäytyvien kompostien bakteeri- ja sieniyhteisöjä, selkeitä eroja kompostin mikrobien valtalajien valikoimissa ei käytetyillä menetelmillä pystytty havaitsemaan. Tuleva tarkempi pyrosekvensointiteknologiaan perustuva analyysi saattaa muuttaa tilannetta ja paljastaa mahdollisesti kompostin taudinehkäisykyvyn kannalta tärkeitä yksittäisiä bakteeri- ja/tai sienilajeja. Alustavien kemiallisten analyysien perusteella (UPLC-TOF-MS) näyttäisi siltä, että tietyt orgaaniset yhdisteet tai mikrobiaineenvaihduntatuotteet olisivat läsnä ainoastaan tautia ehkäisevissä kompostiseoksissa. Näiden yhdisteiden tunnistus on käynnissä.

\section{Kirjallisuus}

Benhamou, N. \& C. Garand. 2001. Cytological analysis of defense-related mechanisms induced in pea root tissues in response to colonization by nonpathogenic Fusarium oxysporum. Phytopathology 91:730-740.

Boulter, J. I., Boland, G. J., \& Trevors, J. T. 2002. Evaluation of composts for suppression of dollar spot (Sclerotinia homoeocarpa) of turfgrass. Plant Disease 86: 405-410.

Chen, W., Hoitink, H. A. J., Schmitthenner, A. F. \& Tuovinen, O. H. 1988. The role of microbial activity in suppression of damping off caused by Pythium ultimum. Phytopathology 78:1447-1450.

Danon, M., Zmora-Nahum, S., Chen, Y. \& Hadar, Y. 2007. Prolonged compost curing reduces suppression of Sclerotium rolfsii. Soil Biolology and Biochemistry 39:1936-1946.

Gorodecki, B. \& Hadar, Y. 1990. Suppression of Rhizoctonia solani and Sclerotium rolfsii disease in container media containing composted separated cattle manure and composted grape marc. Crop Protection 9: 271-274.

Hadar, Y. \& Gorecki, B. 1991. Suppression of germination of sclerotia of Sclerotium rolfsii in compost. Soil Biology and Biochemistry 23: 303-306.

Hoitink, H.A.J. \& Boehm, M.J. 1999. Biocontrol within the context of soil microbial communities: a substratedependent phenomenon. Annual Review of Phytopathology 37: 427-446.

Hoitink, H.A.J. \& Poole, H.A. 1976. Composted bark medium for control of soil-borne plant pathogens. American Nurseryman 144: 15, 88-89.

Hoitink, H.A.J., Stone, A.G. \& Han, D.Y. 1997. Suppression of plant disease by composts. HortScience 32: 184-187.

Hultman, J., Vasara T., Partanen, P., Kurola, J., Kontro M.H., Paulin, L., Auvinen, P., Romantschuk, M. 2009. Determination of fungal succession during municipal solid waste composting using a cloning-based analysis. Journal of Applied Microbiology doi:10.1111/j.1365-2672.2009.04439.x

Itävaara, M., Vikman, M. \& Venelampi, O. 1997. Windrow composting of biodegradable packing materials. Compost Science and Utilization 5: 84-92.

Kuter, G.A., Hoitink, H.A.J. \& Chen, W. 1988. Effects of municipal sludge compost curing time on suppression of Pythium and Rhizoctonia diseases of ornamental plants. Plant Disease 72: 751-756.

McKellar, E. \& Nelson, E.B. 2003. Compost-induced suppression of Pythium damping-off is mediated by fattyacid-metabolizing seed-colonizing microbial communities. Applied and Environmental Microbiology 69: 452460.

Nakasaki, K., Hiraoka, S. \& Nagata, H. 1998. A new operation for producing disease-suppressive compost from grass clippings. American Society for Microbiology 64: 4015-4020. 
Oka, Y. and Yermiyahu, U. 2004. Suppressive effects of composts against the root-knot nematode Meloidogyne javanica on tomato. Nematology 4: 891-898.

Postma, J., Montanari, M. \& van den Boogert, P.H.J.F. 2003. Microbial enrichment to enhance the disease suppressive activity of compost. European Journal of Soil Biology 39: 157-163.

Raviv, M. 2008. The use of compost in growing media as suppressive agent against soil-borne disease. Acta Horticulturae 779: 39-49.

Raviv, M. 2009. Recent advances in soil-borne disease control using suppressive media. Acta Horticulturae 819: $125-134$.

Schönfeld, J., Gelsomino, A., van Overbeek, L.S., Gorissen, A., Smalla, K. \& van Elsas, J.D. 2003. Effects of compost addition and simulated solarisation on the fate of Ralstonia solanacearum biovar 2 and indigenous bacteria in soil. FEMS Microbiology Ecology 43: 63-74.

Serra-Wittling, C., Houot, S. and Alabouvette, C. 1996. Increased soil suppressiveness to Fusarium wilt of flax after addition of municipal solid waste compost. Soil Biology and Biochemistry 28: 1207-1214.

Suárez-Estrella, F., Vargas-García, C., López, M.J., Capel, C ja Moreno, J. 2007. Antagonistic activity of bacteria and fungi from horticultural compost against Fusarium oxusporum f.sp. melonis. Crop Protection 26: 46-53.

Termorshuizen, A.J., van Rijn, E., van der Gaag, D.J., Alabouvette, C., Chen, Y., Lagerlöf, J., Malandrakis, A.A., Paplomatas, E.J., Rämert, B., Ryckeboer, J., Steinberg, C. \& Zmora-Nahum, S. 2006. Suppressiveness of 18 composts against 7 pathosystems: variability in pathogen response. Soil Biology \& Biochememistry 38: 3461-3477.

Yogev, A., Raviv, M., Hadar, Y., Cohen, R. \& Katan, J. 2006. Plant waste-based composts suppressive to diseases caused by pathogenic Fusarium oxysporum. European Journal of Plant Pathology 116: 267-278.

Zhang, W., Han, D.Y., Dick, W.A., Davis, K.R. \& Hoitink, J.A.J. 1998. Compost and compost water extractinduced systemic acquired resistance in cucumber and Arabidopsis. Phytopathology 88: 450-455. 